\section{PROVI(DE)NCIAL VISIONS FOR A MORE-THAN-HUMAN ANTHROPOCENE INCLUDING AI. A RESPONSE BY ANNE DIPPEL TO THE TWO PREVIOUS COMMENTARIES}

\author{
Anne Dippel \\ Department of Cultural Anthropology/Cultural History \\ Friedrich Schiller University of Jena
}

\section{INTERVENTIONS_SUBJECTIVITIES I}

Once upon a time, science set out to end scholastic truth-making by establishing standards of clean objectivity. But a new generation needs space, and as the academic genealogies are an endogamic system that combines tradition-cumindividuation, new thoughts have to stand up against the already established concepts. Decades ago, French postmodernism crossed the great pond. Crisp thoughts pledging for an end of clear-cut objectivities, authorities and hierarchies reached out to sharp thinkers of the American civil rights movement as well as feminists that were trained in philosophic traditions of Williard Van Orman Quine, semiotic reasonings in the aftermath of Charles Sanders Peirce and anthropological thinking after Franz Boas. Male and female postmodern thinkers from the European continent, among them Roland Barthes, Jacques Derrida, Gilles Deleuze, Felix Guattari, Michel Foucault, and Julia Kristeva, inspired post-colonial discursive academics in the United States of America and around the globe. And something profound was about to happen. Slowly, but steadily, the understandings of discursive practices, assemblages, situatedness, and the post-colonial dissection of European patriarchalimperial and racist-colonial hegemony rewrote the DNA of academic reasoning. The subversion of normativity and its power principles were necessary and within the realms of humanities and social sciences astonishingly successful. The decentering of Europe was just a precursor to an existential decentering of the Anthropos. Within the new dispositive, humans at its best are turning into "terrans» (Viveiros de Castro and Danowski, 2018: 172), aspiring to recalibrate their inner «axis of sense» (Yussof, 2018: 73).

Today, we are witnessing an atmospheric shift on a grand scale, to say it with Max Weber. Knowledge in a more-than-human Anthropocene (Tsing et al., 2020) thrives in the logic circuits of if-then-while relations, nurturing dreams of approaching truth based on probabilities and approximation. Artificial Intelligence is just the most prominent of such examples. Alongside automated modes of objectivity/modalities of imaginaries, paradoxically many of us seem to accept that knowledge is based on subjectivities, on experiences and that "truth is more biographical» (Puig de la Bellacasa, 2017: 21).

Beyond autoethnographic modes of research, it becomes increasingly more acceptable to argue from subjective points of view. Although in my essay on the metaphors behind $\mathrm{Al}$, I have contrasted concepts of intelligence with concepts of care on the basis of personal experiences, I remain ambivalent about the method under question. Subjective points claim authority over the position of an I that runs danger of becoming un-falsifiable, claiming truths based on correlations, and setting axioms on the basis of personal impressions. Above all, ethnography has mastered balancing on the thin line between objective empirical observation and the re-situation of this knowledge in self-reflexion of the observer. This may explain its current appeal to so many other disciplines. Through ethnography, we are able to enter into the depths of fake (Dippel, 2021: 9; Severi, 2018: 50; Wittgenstein, 2009: 111, 594, 664) and tend to read and see what our goggles, pre-judices (Gadamer, 1989), bubbles and methods allow us to understand and see. 
We need translations, mediations and re-negotiations. We need authors that meet their critics, not as competitors but as critical allies. Reading the reflections and impressions to my piece, I felt above all grate -and thankful for being invited by Nuria Valverde Pérez and taken so seriously by my critics. Rebeca Ibáñez Martín and Gabriela Méndez Cota demonstrate both in their own way how matters of fact turn into matters of concern (Latour, 2008). In a world of many worlds (de la Cadena and Blaser, 2018), we are torn between a common struggle to find a universally-and-situated ethics within technoscientific nature/cultures of the Anthropocene. We need realizations that our positions and points of views are and must be different, antagonistic and at best supplementary (Derrida, 1976). Dialogue is key. We need to stand together in order to save the planet from what we have done and continuously keep doing to it. In re-thinking what our different feminist points of views bring to the fore, we are showing, as well, what the current issues, productions and outcomes of Artificial Intelligence lack. Alongside such thinkers as Ruha Benjamin (2019a, 2019b), Simone Browne (2015) and Michelle Wright (2005) amongst many others who study racism encoded in $\mathrm{Al}$, we have to tinker, play and (dis-)entangle ourselves with algorithms to re-negotiate their possibilities of empowerment and inclusion for the biggest club of humankind: womanhood, so united and yet so different.

\section{INTERSECTIONS_SUBJECTIVITIES II}

After two years of changing diapers accompanied by two lockdowns all the while working as a full time academic, I can personally relate to the following point: yes, care work is dirty. Even more so, care work exposes hierarchies and social injustices. The essay was written in an overwhelming truly Augustinian moment: the now-as-eternity experienced in childbed. When my baby was not even able to smile back and I not able to sleep, I felt it as obligation to report and remember what profound change of horizon motherhood brought with it. Impressed by the Naturgewalt of birth, empowered by my uterine force, united with all women who were my foremothers in an experience of survival, I carelessly (or rather with too much care) glossed over important critical studies of mother-child-relations (Rose, 1983; Puig de la Bellacasa, 2017). I did not include social motherhoods, fatherhoods and all other forms of nonbinary parenting. In my considerations on care, I did not include for a second my father, who has taught me how to care, love and think; how to be an independent person. What a defeat for someone thoroughly trained in constructivism and deconstructions.

Every er-kennen (insight/knowing) includes a ver-kennen (misjudgment). For most of my life, I was able to evade heteronormative forces and claims on womanhood in the patriarchy, simply by modes of desire. I have never desired men and since early puberty I had known this consciously. I was even able to give my desire a name. Becoming a lesbian in my generation was not free of fear. Often, it was a scary adventure. It required to take courage and leave traditions. In my short lifetime, I witnessed how the $L$ and $G$ community merged, $B$ and $T$ got accepted; $I$, $Q, A$, and now non-binaries joined the club of nonnormativity, turning identity into a colorful spectrum constantly in flux. These fights for sexual identity were happening not in discursive realms but inscribed themselves literally on and within my body/mind as battlefields. Becoming a mother was neither demanded nor taken for granted, or even something I had on my wish list for most of my life. At least consciously. To understand what my desires include, to attain a life condition that gave me confidence and stability for becoming a mother was a struggle, and without my partner, I would have neither dared nor tried. I am forever grateful for generations of often childless intellectuals who paved the way for me. I am a multiplicity, a member of a cosmopolitan rainbow family, intersectional mother to an even more intersectional child, and so my intelligence, my voice as well as my motherhood are modes of empowerment and proves of inclusion in an exclusive society. They are both, political acts, and private fulfillments. They are possible within a system of welfare, freedom, and tolerance. They thrive without classical networks of family care performed by elders, aunts, grandparents, or cousins. A chosen kin in a global queer village is raising our child. Thanks to them I am able to keep writing those lines.

The acknowledgement of inclusion in my society of origin and the experience of empowerment and courage are weighing even more, considering the fact that I come from a country, where motherhood and womanhood used to be objectified, minimized, politicized, weaponized and militarized. German is the language of Sigmund Freud's hysteric case of Anna O., the social pioneer and feminist Bertha Pappenheim. Germany is the country where women were either sterilized and gassed or adorned with medals for getting children like brave soldiers for 
doing their lethal work of war. Consciously becoming a mother in this post-totalitarian, post-traumatic, and still-patriarchal society (until today granting male philosophers and scientists so much more discursive space and economical possibilities) was not an easy decision; rather a transition and something I came to understand as a queer form of resistance. My motherhood is not that kind of German motherhood Elisabeth Badinter (1980) wonderfully described nor that kind of first-generation psychoanalytically aware and feminist motherhood Barbara Sichtermann (1981) envisioned. The body multiple (Mol, 2002) of mine has entered a new phase of identity and I am struggling along with all the other mothers with their different layers of intersection to raise children that are different and give hope in a world of neoliberal acceleration, algorithmic deceptions, and strongman politics. As the pandemic unfolds, true qualities of $\mathrm{Al}$ lie in collaborations with humans. Together we should be allies in a struggle for saving the ecosphere and biosphere instead of conjuring "pristine» (Law and Lien, 2018: 135) worlds of algorithmic manufacturing.

In times of pandemic, when viruses alongside with other "terrans» (Viveiros de Castro and Danowski, 2018: 172) wage war against the human world, the limits of any seclusionary intelligence become clear. The current condition asks for new languages and re-considerations of established modes of thinking (Braidotti, 2013). I am a human, but what does it mean and what does it exclude? And who is on my side, regardless of biological or technological origin and hybrid identity? We need new visions, new words, new actions. We need more understanding through translations and engagements. We need to listen to all the others, even the others within ourselves, looking into "the gaps left in us by the secrets of others» (Abraham, 1987: 287).

\section{TRANSLATIONS_CARING ABOUT WHAT HAS TO BE CARRIED ACROSS: AGAIN, AND AGAIN}

Usually, I write in German, so I tend to feel as if I was losing my ground whenever I try to make a point in English; a language far less embodying than my mother tongue when it comes to naming abstract concepts (Goldschmidt, 2006). Thinking of Al as alien, I was not going into the footsteps of Hollywood science fiction fantasies, but rather thinking about birds with Claude Levi-Strauss or octopuses living in Alien Oceans (Helmreich, 2009), or alien phenomenology (Bogost, 2012). Thus, I take the inspirations for getting to know
Joanna Zylinska's work as point of departure and would add to my lockdown-reading list Marge Piercy's He, She and It (1991) as well as K Allado-Mcdowell's Phramako-Al (2021), which envisions a way out of binaries of womanhood and manhood. After all, as Al is not only made by men, children are not only raised and cared for by women.

The English word care stems from Latin cura (to cure). The German equivalent Sorge is related to sorrow. When asking for reconsidering what sorgen as political practice means in the Anthropocene, I remain trapped within German traditions of philosophy and have to distance myself immediately from Martin Heidegger, the grumpy humanexceptionalist (Haraway, 2013). For me, doing academic work in different languages is one of the pathways to allow difference and sameness to coexist side by side. We live in a world of hegemonic English, where gerundive arguing turns into a fashion of fact-making. Surely without English as our common lingua franca, Ibáñez Martín, Méndez Cota, and I would have never been able to have this wonderful academic exchange. Algorithms are simply not suited to do this kind of translation. However, we still need to find a common ground. Our different readings of what alien means and how we perceive Artificial Intelligence, show how language shapes the horizon of our perception and how it affords us to listen careful (Wittgenstein, 2009). It is not only experience that matters, but also how world is narrated and read. This reminder goes for any sort of dialogue and encounter, no matter whether interspecies, intercontinental, intergenerational, or international. While in lockdown, I keep looking out for more words of Spanish and Indoamerican origin and other indigenous languages in the hope of relocating and re-framing thinking about technology in the anthroposceneries and algorithmic-scapes of the now as well as the future contemporary.

The mantra of this tripartite thank you to my critics returns: Every er-kennen goes along with a ver-kennen. As a child of continental European scientific beliefs and post-monotheistic world views, I chose the metaphor of alien. Méndez Cota's reading of my metaphor reminded me that Europe is a ruinous and ruined place that needs to be decentered and provincialized (Chakrabarty, 2007). But perhaps, it is fruitful to listen to this rich, ruined, and ruinous province and look at its inhabitants with more empathy. Writing from the privileged safe net 
of a still functioning democracy and a welfare state who takes care of me, I have come to understand that aliens are my provincial phantasy of how to think the other. Based in folklore studies and trained in psychoanalytic writings, this includes of course the other in me. Méndez Cota's reply reminds me of where I am from and shows that locality matters. Nevertheless, I need to say that most provinces tend to be underrated by those who are not in a certain province and overrated by those who come from a certain one. As the German saying goes: Provinz ist, wo ich bin (province is, where I am). Therefore, I am calling for a minor anthropology, with Franz Kafka, Gilles Deleuze and Félix Guattari in mind (1975/1986).

As often, good comedy makes all this much clearer than any sophisticated argumentation could ever make. In a sketch, Benaissa Lamroubal -a German comedian with Moroccan heritage- recounts his visit to a small village in the Moroccan countryside. While playing with his cousins, he is trying to explain what "aliens» are. "They come from another world and land here on Earth", to which one of his cousins replies "No, believe me, that's a djinn!» Benaissa wonders how come Moroccans have not heard of aliens, drawing a conclusion that no one in Africa has: "No alien has landed in Morocco yet". Throughout the rest of the sketch, he tries to make sense of this experience, resuming «No Aliens in whole Africa. Even if you ask around. -I mean, what do aliens actually do?- Aliens come from another world. They visit in huge ships- and either kidnap people or take over their entire land. -In Africa, such people are called 'Europeans' ${ }^{1}$ (Lamroubal, 2020, my translation).

Yes. Aliens are the symbolization of the ghostly fear of what Europeans have been to many Africans. And it is about us Europeans to recognize the "Alien within», rework our past and provincialize ourselves to become part of the "terranic» sphere and understand the inhumane dimensions of what it means to sort and assort the world within and through the cosmologies that dominated us and helped to dominate and colonize "the other» (including those, who were and are othered on the European turf).

Now for that reason, I do and do not want to give up the concept of Artificial Intelligence as alienus, as Anderes. Nor do I want to turn it into a half-godspirit just as djinns are. This sketch shows that each metaphor has its boundaries and its historical and situational flaws. Al is coded and yes, it is encoded with «discriminatory designs» (Ruha, 2019b: 4), made with and through extractivist, colonial dispositives (Yussof, 2018). A contestable concept such as Al as alien does exactly what it needs to do: it does not explain "the difference away» (De La Cadena and Blaser, 2018: 7), but opens up a space for discussions. As much as we need critical investigations of code, we have to wonder what algorithmic things are to us and potentially become in a more-than-human world, in order to be able to resist if necessary. While Artificial Intelligence as such is a metaphor we have to live with, what $A l$ is and what its potential to become may be, should not be simply colonized by what humans think they are, or for example European provincials fear and desire, but acknowledging that Al is part of a more-than-human-world. This means to take what we do serious, but to take ourselves not too serious at the same time in order to find new ways without forgetting where we came from. The capacity of decentering oneself through laughter allows to "reappropriate a toxic terrain, a field of domination, making it again capable of nurturing" (Puig de la Bellacasa, 2017: 11) -especially when it comes to care that had been (ab)used in colonial context (Murphy, 2015). Thus, care becomes a form of intervention (Mol, 2008: 84). It supplements the manifolds of knowledge on planet earth which allows us to stay with the trouble (Haraway, 2016). That is why cyberfeminist collectives such as Deep Lab or institutions such as Al Now are important companions and allies when it comes to re-thinking Al beyond male dominant master narratives encoded into algorithmic designs. We need $\mathrm{Al}$ as terran ally when it comes to fighting climate change and other matters of concern in a more-than-human world.

This brings me back to the main point of my essay: How should we strive for a language and living along with technoscientific agents, phenomena, and natural/cultural multispecies-entanglements without falling into the traps of techno philia or -phobia? How to include $\mathrm{Al}$ in a more-than-human world to allow the other to be the other-same same, but different?

1 The TV-sketch from Benaisa Lamroubal Integration. Rebel Comedy: Hoch ansteckend was showed at Westdeutscher Rundfunk the 25th August 2020. Lamroubal posted it on Facebook the 24th November 2020 and it is available at: https://fb.watch/62UC1PVqOK/ 


\section{REFERENCES}

Abraham, Nicolas (1987). Notes on the Phantom: A Complement to Freud's Metapsychology. Critical Inquiry. The Trials of Psychonalysis, 13 (2): 287-292.

Allado-Mcdowell, K. (2021). Pharmako-Al. Ignota Books.

Badinter, Elisabeth (1980). L'amour en plus. Histoire de l'amour maternel XVIlème siècle-XXème siècle. Paris: Flammarion.

Benjamin, Ruha (2019a). Race after Technology. Abolitionist Tools for the New Jim Code. Cambridge: Polity Press.

Benjamin, Ruha (ed.) (2019b). Captivating Technology. Race, Carceral Technoscience and Liberatory Imagination in the Everyday Life. Durham: Duke University Press.

Braidotti, Rosi (2013). The Posthuman. Cambridge: Polity Press.

Bogost, Ian (2012). Alien Phenomenology, or What It's Like to Be a Thing. Minneapolis: University of Minnesota Press.

Browne, Simone (2015). Dark Matters. On the Surveillance of Blackness. Durham: Duke University Press.

Chakrabarty, Dipesh (2007). Provincializing Europe: Postcolonial Thought and Historical Difference. Princeton: Princeton University Press.

De La Cadena, Marisol and Blaser, Mario (eds.) (2018). A World of Many Worlds. Durham: Duke University Press.

Deleuze, Gilles, Guattari, Félix (1975/1986). Kafka. Toward a Minor Literature. Minneapolis: University of Minnesota Press.

Derrida, Jacques (1967/1976). Of Grammatology. Baltimore: Johns Hopkins University Press.
Dippel, Anne (2021). Schwindel in der Digitale. Re/Visionen einer Kulturanalyse des Alltags. In: Kuckuck. Notizen zur Alltagskultur, 6-10.

Gadamer, Hans-Georg (1960/1989). Truth and Method. London: Sheed and Ward.

Goldschmidt, George-Arthur (2006). Quand Freud voit la mer. Freud et la langue allemande I. Paris: Buchet et Chastel.

Haraway, Donna (2013). SF: Science Fiction, Speculative Fabulation, String Figures, So Far. Ada: A Journal of Gender, New Media, and Technology, 3. Available at: https://adanewmedia.org/2013/11/ issue3-haraway/ [Last Retrieved: 13. February 2021]

Haraway, Donna J. (2016). Staying with the trouble: Making kin in the Chthulucene. Durham: Duke University Press.

Helmreich, Stephan (2009). Alien ocean: Anthropological voyages in microbial seas. Berkley, Los Ángeles and London: University of California Press.

Latour, Bruno (2008). What is the Style of Matters of Concern? Two Lectures in Empirical Philosophy. Assen: Koninklijke Van Gorcum.

Law, John and Lien, Marianne (2018). Denaturalizing Nature. In: De La Cadena, Marisol and Blaser, Mario (eds.). A World of Many Worlds. Durham: Duke University Press, pp. 131-171.

Murphy, Michelle (2015). Unsettling Care: Troubling Transnational Itineraries of Care in Feminist Helath Practices. Social Studies of Science, 45 (5): 717-37.

Mol, Annemarie (2002). The Body Multiple: Ontology in Medical Practice. Durham: Duke University Press.

Mol, Annemarie (2008). The Logic of Care: Health and the Problem of Patient Choice. New York: Routlege.
Piercy, Marge (1991). He, She, and It. New York: Knopf.

Puig de la Bellacasa, María (2017). Matters of Care. Speculative Ethics in More Than Human Worlds. University of Minnesota Press: Minneapolis.

Rose, Hilary (1983). Hand, Brain, and Heart: A Feminist Epistemology for the Natural Sciences. Signs: Journal of Woman in Culture and Society, 9 (1): 73-90.

Severi, Carlo (2018). Fake as knowledge and relationship. In Copeman, Jacob and da Col, Giovanni: Fake. Anthropological Keywords. Chicago: HAU Books.

Sichtermann, Barbara (1981). Leben mit einem Neugeborenen. Fischer: Frankfurt am Main.

Tsing, Anna L.; Deger, Jennifer; Saxena, Alder Keleman; and Zhou, Feifei (2020). Feral Atlas. The More-Than-Human Anthropocene. A STANFORD DIGITAL PROJECT available at: http://feralatlas. org [Last Retrieved: 13 February 2021].

Vickers, Ben and Mcdowell, Kenric (eds.) (2020). Atlas of Anomalous Al. Ignota Books.

Viveiros De Castro, Eduardo and Danowski, Déborah (2018). Humans and Terrans in the Gaia War. In: Marisol De La Cadena and Mario Blaser (Eds.). A World of Many Worlds. Durham: Duke University Press, pp. 131-171.

Wright, Michelle (2005). Finding a Place in Cyberspace: Black Women, Technology, and Identity. Frontiers: A Journal of Women Studies, 26 (1): 48-59.

Wittgenstein, Ludwig (2009). Philosophical Investigations. Oxford: Blackwell.

Yussof, Kathryn (2018). A Billion Black Anthropocenes or None. Minneapolis: University of Minnesota Press. 